JURNAL KETAHANAN NASIONAL

Vol. 24, No. 3, Desember 2018, Hal 354-373

DOI:http://dx.doi.org/ 10.22146/jkn.38753

ISSN:0853-9340(Print), ISSN:2527-9688(Online)

Online sejak 28 Desember 2015 di :http://jurnal.ugm.ac.id/JKN

VOLUME 24

No. 3, Desember 2018

Halaman 354-373

\title{
Pengaruh Proses Pelaporan Dan Penyetoran Pajak Serta Kepuasan Dan Kepatuhan Dalam Wajib Pajak Pribadi Kabupaten Sleman Terhadap Ketahanan Ekonomi Wilayah
}

\author{
Diki Ferdiana \\ Kementrian Hukum dan Ham Jakarta \\ Email: Dikiferdiana30@gmail.com \\ Ayu Chairina Laksmi \\ Universitas Islam Indonesia \\ Email: ayu_chairina@yahoo.com
}

\begin{abstract}
This study examinedthe influence of the process of reporting and depositing taxes as well as satisfaction and compliance in personal tax payers in Sleman regency against economic resilience. The purpose of this study was to analyzed the influence of the process of reporting and depositing taxes and taxpayer compliance and compliance with economic resilience.

This research was an empirical research by taking samples of taxpayers in Sleman District. Survey data were analyzed statistically using descriptive method and Structural Equation Modeling (SEM) with the help of computer program AMOS $v 22$.

The results showed that the process of reporting and depositing taxes and satisfaction and compliance in taxpayershad posistive influence, which had a significant impact on the economic resilience of the region. This could be said as a form of economic resilience of the region which was the basis of national resilience
\end{abstract}

Keywords: Tax Reporting And Depositing, Tax Satisfaction And Compliance, Regional Economic Resilience

\begin{abstract}
ABSTRAK
Penelitian ini mengkaji tentang pengaruh proses pelaporan dan penyetoran pajak serta kepuasan dan kepatuhan dalam wajib pajak pribadi di Kabupaten Sleman terhadap ketahanan ekonomi. Tujuan penelitian ini untuk menganalisis pengaruh proses pelaporan dan penyetoran pajak serta kepuasan dan kepatuhan wajib pajak terhadap ketahanan ekonomi.

Penelitian ini merupakan penelitian empiris dengan mengambil sampel para wajib pajak di Kabupaten Sleman. Data survei dianalisis secara statistik menggunakan metode deskriptif dan Structural Equation Modeling (SEM) dengan bantuan program komputer AMOS v22.

Hasil penelitian menunjukkan bahwa proses pelaporan dan penyetoran pajak serta kepuasan dan kepatuhan dalam wajib pajak berpengaruh posistif, yang berdampak signifikan terhadap ketahanan ekonomi wilayah. Hal ini dapat dikatakan sebagai wujud dari ketahanan ekonomi wilayah yang merupakan dasar dari ketahanan nasional.
\end{abstract}

Kata Kunci: Pelaporan Dan Penyetoran Pajak, Kepuasan Dan Kepatuhan Pajak, Ketahanan Ekonomi Wilayah 


\section{PENGANTAR}

Ketahanan nasional merupakan sebuah konsepsi pertahanan yang bersifat semesta, serta bertujuan untuk kelangsungan hidup bangsa dan Negara Indonesia yang merdeka dan berdaulat dengan mendasarkan pada kekuatan diri sendiri. Sistem ketahanan nasional pada dasarnya bersifat semesta bercirikan pada kerakyatan, artinya hal tersebut diorientasikan untuk kepentingan rakyat. Berdasarkan hal tersebut, maka sumber daya (SDA dan SDM) yang ada didayagunakan sebagai upaya kepentingan sekaligus pertahanan nasional, maka konsepsi ketahanan nasional Indonesia mencakup seluruh kehidupan nasional, dirinci menjadi delapan aspek kehidupan, atau sering disebut sebagai Astagatra, yang terdiri dari trigatra dan pancagatra. Unsur trigatra meliputi aspek geografi, kekayaan alam dan kependudukan. Pancagatra merupakan aspek-aspek kehidupan nasional yang menyangkut tata kehidupan dan pergaulan hidup manusia dalam bermasyarakat dan bernegara yang diikat dengan aturanaturan dan norma tertentu.

Setiap negara sudah semestinya mempunyai tugas dan tanggung jawab untuk menjaga dan melindungi kedua spek tersebut, baik yang bersifat alamiah maupun yang bersifat sosial. Tugas dan tanggungjawab tersebuut tidak hanya dibebankan pada aparatur atau perangkat kenegaraan semata, akan tetapi semua warga negara juga mempunyai tugas dan tanggung jawab secara bersama untuk mempertahankan kedua aspek tersebut. Hal ini dilakukan supaya kedaulatan negara, keutuhan wilayah NKRI, keadilan dan kesejahteraan rakyat serta keselamatan segenap bangsa dapat terjaga dan terjamin dari segala bentuk ancaman baik dari dalam negeri maupun dari luar negeri. Salah satu gatra dalam mewujudkan ketahanan nasional adalah aspek ekonomi sebagai salah satu gatra dalam konsepsi ketahanan nasional yang merupakan faktor penting bagi kemajuan dan kesejahteraan sebuah bangsa. Semakin tinggi laju pertumbuhan ekonomi suatu negara seringkali menjadi tolok ukur kesejahteraan rakyat dan kemajuan sebuah bangsa. Bahkan perekonomian suatu negara dapat mempengaruhi kondisi sosial dan politik. Artinya, konflik sosial dan stabilitas politik yang dapat mengancam disintegrasi bangsa seringkali dipengaruhi oleh faktor ekonomi. Begitupula dengan pembangunan, baik dari segi infrastruktur maupun suprastruktur juga membutuhkan prasyarat ekonomi. Maka dari itu, stabilitas dan laju pertumbuhan ekonomi perlu diwujudkan agar ketahanan nasional terwujud. Kaitannya dalam mewujudkan ketahanan nasional, khususnya dalam bidang ekonomi, seperti yang diulas diatas harus melibatkan semua elemen yang ada, salah satunya adalah pajak. Membayar pajak adalah salah satu kewajiban bagi setiap orang dalam sebuah negara terutama di Indonesia. Pajak bersifat dinamik dan mengikuti perkembangan kehidupan sosial, ekonomi, negara serta masyarakatnya, sehingga para pelaku perpajakan baik yang mengatur maupun yang diatur harus mengerti perkembangan kehidupan sosial, ekonomi, masyarakat dan negaranya. Sebagai warga negara yang baik seharusnya taat dalam membayar pajak. Sampai saat ini masih banyak dilema mengenai pajak baik dalam kepatuhan, ketertiban, dan yang terpenting adalah dalam bidang administrasinya. Masalah ini seharusnya benar-benar diperhatikan untuk perubahan yang lebih baik dan teratur dalam aspek perpajakan. Tuntutan akan perbaikan-perbaikan dan perubahan mendasar 
dalam segala aspek perpajakan menjadi alasan dilakukannya reformasi perpajakan dari waktu ke waktu. Perbaikan ini berupa penyempurnaan terhadap kebijakan perpajakan dan sistem administrasi perpajakan, agar basis pajak dapat semakin diperluas. Dengan demikian potensi penerimaan pajak yang tersedia dapat dipungut secara optimal dengan menjunjung asas keadilan sosial dan memberikan pelayanan prima kepada wajib pajak. Kepatuhan wajib pajak dimungkinkan menjadi salah satu variabel yang berperan besar dalam menentukan penerimaan pajak.

Kepatuhan wajib pajak (tax compliance) dapat diidentifikasi dari ketaatan wajib pajak dalam memenuhi persyaratan, mendaftarkan diri, dan kepatuhan untuk mengembalikan surat pemberitahuan (SPT) yang sudah diisi lengkap, kepatuhan mengisi lengkap surat setoran pajak (SSP), kepatuhan dalam penghitungan dan pembayaran pajak terutang, dan kepatuhan dalam pembayaran tunggakan. Kepatuhan menjadi penting karena ketidakpatuhan secara bersamaan akan menimbulkan upaya menghindarkan pajak, yang mengakibatkan berkurangnya penyetoran dana pajak ke kas negara (APBN). Pada hakikatnya kepatuhan wajib pajak dipengaruhi oleh kondisi sistem administrasi perpajakan. Perbaikan administrasi perpajakan sendiri diharapkan dapat mendorong kepuasan dan kepatuhan wajib pajak. Pelayanan yang diselenggarakan oleh Kantor Pelayanan Pajak dapat dikategorikan sebagai pelayanan publik, merupakan instansi pemerintah serta unsur pelaksana Direktorat Jenderal Pajak sedangkan DJP merupakan instansi yang berada di bawah Kementerian Keuangan (Kemenkeu) yang merupakan kementerian milik Pemerintah Pusat. KPP dibentuk untuk memberikan pelayanan perpajakan kepada para wajib pajak sebagaimana termaktub dalam Peraturan Menteri Keuangan No. 206.2/ PMK.01/2014 tentang Organisasi dan Tata Kerja Instansi Vertikal Direktorat Jenderal Pajak.Pelayanan yang diselenggarakan oleh KPP adalah dalam rangka upaya pemenuhan kebutuhan masyarakat wajib pajak dan pelaksanaan ketentuan peraturan perundangundangan. Oleh karena itu, sudah semestinya KPP memberikan pelayanan terbaik kepada wajib pajak. Pelayanan merupakan kata kunci untuk melaksanakan tugas yang diemban oleh pegawai pajak. DJP juga mengemban pekerjaan untuk mengubah citra yang selama ini terbentuk di masyarakat. Masyarakat menganggap bahwa mengurus pembayaran pajak itu susah, prosesnya berbelit-belit, dan masih dijumpai adanya pegawai di kantor pajak yang bersikap kurang santun dan kurang ramah saat melayani wajib pajak (Surjoputro dkk, 2009). Sejak tahun 2001 DJP telah menggulirkan reformasi administrasi perpajakan dengan tujuan tercapainya tingkat kepatuhan sukarela yang tinggi; tingkat kepercayaan terhadap administrasi perpajakan yang tinggi; dan produktivitas pegawai perpajakan yang tinggi. Program dan kegiatan reformasi administrasi perpajakan diwujudkan dalam penerapan sistem administrasi perpajakan modern yang memiliki ciri khusus antara lain struktur organisasi berdasarkan fungsi, perbaikan pelayanan bagi setiap wajib pajak melalui pembentukan account representative dan compliant center untuk menampung keberatan wajib pajak. Selain itu, sistem administrasi perpajakan modern juga merangkul kemajuan teknologi terbaru di antaranya melalui pengembangan sistem informasi perpajakan (SIP) dengan pendekatan fungsi menjadi sistem administrasi perpajakan terpadu (SAPT) yang dikendalikan oleh 
casemanagement sistem dalam workflow sistem dengan berbagai modul otomasi kantor serta berbagai pelayanan dengan basis e-sistem seperti e-SPT, e-Filing, e-Payment, Taxpayers'Account, e-Registration, dan e-Counselling yang diharapkan meningkatkan mekanisme kontrol yang lebih efektif ditunjang dengan penerapan kode etik pegawai DJP yang mengatur perilaku pegawai dalam melaksanakan tugas. Pelayanan-pelayanan tersebut sudah tentu dimaksudkan untuk meningkatkan pelayanan kepada masyarakat wajib pajak. Dengan demikian, wajib pajak akan merasa dimudahkan dan puas atas pelayanan kantor pajak, yang pada akhirnya mampu menumbuhkan kepatuhan sukarela untuk membayar pajak.

Pada tahun 2016 Kanwil DJP DIY menyatakan bahwa hingga tahun 2016 di Provinsi DIY masih terdapat ketidakpatuhan wajib pajak, yaitu masing-masing 9\% di Kabupaten Sleman dan Kabupaten Gunung Kidul, 19\% di Kabupaten Bantul, 32\% di Kota Yogyakarta, dan 34\% di Kabupaten Kulon Progo. Meskipun secara persentase para wajib pajak yang tidak patuh di Kabupaten Sleman adalah terkecil, namun secara hitungan SPT ternyata para wajib pajak yang tidak patuh di Kabupaten Sleman adalah yang terbesar, sebab jumlah wajib pajak di Kabupaten Sleman adalah yang terbesar di Provinsi DIY, yaitu 37.530 SPT.

Mavengere (2015) melakukan survei untuk mengetahui tingkat kepuasan wajib pajak atas pelayanan yang diberikan oleh Large Taxpayer Office (LTO). Hasil survei tersebut menyatakan bahwa $78 \%$ responden melihat dan merasakan perubahan yang signifikan atas sikap para pegawai pajak di LTO, 84\% responden menyatakan bahwa pemenuhan kewajiban perpajakan menjadi lebih mudah, 13\% menyatakan tidak adanya perubahan, $2 \%$ menyatakan lebih sulit dan $1 \%$ tidak tahu. Indeks tingkat kepuasan yang diperoleh adalah sebesar 81, melampaui ratarata survei di Iran sebesar 75 (Abdul-Razak dkk, 2013). Berdasarkan hasil survei tersebut, dapat diketahui bahwa sebagian besar wajib pajak merasa puas atas pelayanan yang diberikan oleh LTO dari sisi sikap pegawai kantor pajak dan kemudahan mengurus pelaporan dan penyetoran pajak.

Adapun research gap beberapa penelitian terdahulu yang serupa dengan penelitian yang dilakukan oleh Meverenge (2015) adalah penelitian yang dilakukan oleh Jayawardane dkk (2016) serta Abdul-Razak dkk (2013) yang meneliti hubungan antara jasa (layanan) dengan kepuasan wajib pajak pada lingkup kantor pelayanan pajak. Kualitas layanan dan fitur layanan kantor pelayanan pajak berpengaruh positif terhadap kepuasan wajib pajak, sedangkan customer complaint handling yang diselenggarakan oleh kantor pelayanan pajak tidak berpengaruh positif terhadap kepuasan wajib pajak (Jayawardane dkk, 2016). Sementara itu Abdul-Razak dkk (2013) menemukan hubungan positif antara kualitas layanan, citra perusahaan dan biaya pelayanan terhadap kepuasan konsumen pada kantor pelayanan pajak. Dari penelitianpenelitian terdahulu tersebut diketahui bahwa kualitas jasa (layanan), fitur layanan, citra perusahaan, dan biaya pelayanan berpengaruh positif terhadap kepuasan wajib pajak.

Merujuk pada Peraturan Menteri Pendayagunaan Aparatur Negara No. 16 Tahun 2014 Tentang Pedoman Survei Kepuasan Masyarakat Terhadap Penyelenggaraan Pelayanan Publik, dijelaskan bahwa terdapat 9 (sembilan) unsur yang relevan, valid, dan reliabel, sebagai dasar pengukuran survei 
kepuasan masyarakat. Kesembilan unsur tersebut adalah persyaratan, prosedur, waktu pelayanan, biaya/tarif, produk spesifikasi jenis pelayanan, kompetensi pelaksana, perilaku pelaksana, maklumat pelayanan, penanganan pengaduan, saran dan masukan. Atas dasar tersebut, peneliti mengambil 1 (satu) unsur, yaitu prosedur pembayaran pajak untuk dianalisis apakah faktor tersebut berpengaruh positif atau negatif terhadap kepuasan dan kepatuhan wajib pajak.

Unsur prosedur pembayaran yang dianalisis diuraikan lagi menjadi 2 (dua) faktor, yaitu proses pelaporan dan penyetoran pajak. Hal ini dilakukan dengan pertimbangan bahwa sebagai akibat self assesment system, wajib pajak memiliki kewajiban untuk menghitung, membayar, dan melaporkan sendiri pajak terutang ke kantor pajak. Adapun pelayanan publik yang dilakukan oleh kantor pelayanan pajak perlu memenuhi unsur survai kepuasan masyarakat.

Berdasarkan uraian penelitian terdahulu dan research gap di atas, maka peneliti tertarik untuk meneliti lebih jauh pengaruh proses pelaporan dan penyetoran pajak terhadap kepuasan dan kepatuhan wajib pajak orang pribadi di Kabupaten Sleman sebagai kasus khusus di Indonesia. Sehubungan penelitian ini adalah riset ilmiah yang bersifat empiris, maka dalam analisis data digunakan program komputer berbasis statistik, yaitu AMOS v22.0.

Terdapat beberapa teori dalam penelitian ini yang bertujuan untuk mengarahkan penelitian ini agar mudah untuk melakukan penelitian, adapun teori yang dimaksud adalah sebagai berikut.

Pertama, resource based theory yang dipelopori oleh Penrose (1959) (dalam Barney dkk., 2007) mengemukakan bahwa sumber daya yang dimiliki perusahaan bersifat heterogen dan memiliki karakteristik khusus dan unik di setiap perusahaan. Resource based theory adalah suatu pemikiran yang berkembang dalam teori manajemen strategis dan keunggulan kompetitif perusahaan yang meyakini bahwa perusahaan akan mencapai keunggulan apabila memiliki sumber daya yang unggul. Sumber daya yang unggul adalah sumber daya yang langka, susah untuk ditiru oleh pesaing dan tidak tergantikan.

Menurut Barney (2001), agar dapat bersaing organisasi membutuhkan dua hal utama, yaitu (1). Memiliki keunggulan dalam sumber daya yang dimilikinya, baik berupa aset yang berwujud (tangible assets) maupun yang tidak berwujud (intangible assets); (2).Kemampuan dalam mengelola sumber daya yang dimiliki secara efektif dan efisien. Kombinasi yang baik dari keduanya akan menciptakan kompetensi yang khas dari sebuah perusahaan, sehingga mampu memiliki keunggulan kompetitif dibanding para pesaingnya.

Sejalan dengan resource based theory (Barney dkk., 2007; Barney, 2001), kantor pelayanan pajak yang mampu menggunakan dan mengelola sumber daya yang dimilikinya baik berupa aset berwujud maupun aset yang tidak berwujud secara efektif dan efisien maka hal tersebut dapat menciptakan value added dan kepuasan bagi para wajib pajak (Surjoputro dkk, 2009; Gunadi, 2009).

Kedua, teori agensi yang dikemukakan oleh Jensen dan Meckling (1976) (dalam Arifin, 2005) menjelaskan hubungan antara principal (pemilik) dan agent (manajer) dalam hal pengelolaan perusahaan, dimana principal merupakan suatu entitas yang mendelegasikan wewenang untuk mengelola perusahaan kepada pihak agent(manajemen). Perbedaan 
peran di antara keduanya menyebabkan suatu ketimpangan informasi. Chen dkk (2005) menyatakan bahwa teori agensi menggunakan tiga asumsi sifat manusia, yaitu (a). manusia pada umumnya mementingkan diri sendiri (self interest); (b). manusia mempunyai daya pikir terbatas mengenai persepsi masa mendatang (bounded rationality); (c). manusia selalu menghindari risiko (risk averse).

Teori agensi(Chen dkk, 2005; Arifin, 2005) mengindikasikan bahwa kantor pelayanan pajak bukanlah entitas yang hanya beroperasi untuk kepentingannya sendiri namun harus memberikan manfaat bagi para wajib pajaknya. Oleh karena itu pengelolaan sumberdaya yang maksimal dapat meningkatkan kualitas layanan yang kemudian akan menaikkan kepuasan wajib pajak, sehingga kepatuhan pajak pun meningkat (Gunadi, 2009).

Ketiga, teori stakeholder. Teori ini lebih mempertimbangkan posisi para stakeholder yang dianggap powerful. Kelompok stakeholder inilah yang menjadi pertimbangan utama bagi perusahaan dalam mengungkapkan dan/atau tidak mengungkapkan suatu informasi di dalam laporan keuangan. Dalam pandangan teori ini, perusahaan memiliki stakeholders, bukan hanya sekedar shareholder. Perusahaan memandang bahwa stakeholders terdiri dari pemegang saham, kreditur, pemerintah, karyawan, pelanggan, pemasok, dan publik (Fountaine dkk., 2006). Tujuan utama dari teori ini adalah untuk membantu manajemen perusahaan dalam meningkatkan penciptaan nilai sebagai dampak dari aktivitas-aktivitas yang mereka lakukan dan meminimalkan kerugian yang mungkin muncul bagi stakeholder mereka. Sebenarnya, teori ini menjelaskan hubungan antara manajemen perusahaan dengan para stakeholder-nya. Para stakeholder memiliki hak untuk diperlakukan secara adil oleh organisasi, dan manajemen harus mengelola organisasi untuk keuntungan seluruh stakeholder. Dalam upaya penciptaan nilai bagi perusahaan, manajemen perusahaan harus dapat mengelola seluruh sumber daya yang dimiliki perusahaan, baik karyawan (human capital), aset fisik (physical capital) maupun structural capital (Freeman, 2004). Berdasarkan stakeholder theory, Wolk (2001) dan Alfioza dkk (2011) membahas mengenai dorongan para wajib pajak untuk memberikan informasi proses pembayaran pajak, baik informasi proses pelaporan pajak maupun proses penyetoran pajak, dan sebagai sinyal positif bagi kepatuhan para wajib pajak. Kegiatan-kegiatan yang dilakukan oleh kantor pelayanan pajak selalu berdampak kepada kepuasan dan kepatuhan para wajib pajak. Jika kinerja kantor pelayanan pajak berjalan baik maka kantor pelayanan pajak harus memberi informasi kepada pihak wajib pajak agar patuh membayar pajak (Nurmantu, 2008).

Keempat, teori administrasi. Administrasi diartikan sebagai arahan, pemerintahan, kegiatan, implementasi, mengarahkan, penciptaan prinsip-prinsip implementasi kebijakan, kegiatan melakukan analisis, menyeimbangkan dan mempresentasikan keputusan, pertimbangan-pertimbangan kebijakan, sebagai pekerjaan individual dan kelompok dalam menghasilkan barang dan jasa publik, dan sebagai arena bidang kerja akademik dan teoritis. Administrasi merupakan suatu proses yang dinamis dan berkelanjutan, yang digerakkan dalam rangka mencapai tujuan dengan cara memanfaatkan orang dan material melalui koordinasi dan kerjasama. Definisidefinisi di atas menunjukkan beberapa batasan istilah administrasi yang secara langsung menepis anggapan bahwa administrasi selalu 
diartikan sebagai kegiatan ketatausahaan yang berkaitan dengan pekerjaan mengatur berkas, membuat laporan administratif, dan sebagainya (Keban, 2009:2).

Menurut Lumbantoruan (2007:582) dalam ensiklopedi perpajakan yang disebut dengan administrasi perpajakan (tax administration) adalah cara-cara atau prosedur pengenaan dan pemungutan pajak. Administrasi perpajakan diupayakan untuk merealisasikan peraturan perpajakan, dan penerimaan negara sebagaimana amanat APBN. Menurut Gunadi (2009), administrasi pajak dikatakan efektif bila mampu mengatasi masalah-masalah, yaitu wajib pajak yang tidak terdaftar (unregistered taxpayers); wajib pajak yang tidak menyampaikan surat pemberitahuan (SPT); penyelundup pajak (tax evaders); dan penunggak pajak (delinquent tax pavers).

Administrasi perpajakan akan efektif jika keempat permasalahan tersebut dapat diselesaikan. Apabila kebijakan perpajakan yang ada mampu mengatasi masalah-masalah di atas secara efektif, maka administrasi perpajakannya sudah dapat dikatakan baik sehingga tax ratio akan meningkat. Dasar bagi terwujudnya suatu administrasi pajak yang baik adalah diterapkannya prinsipprinsip manajemen modern, yaitu planning, organizing, actuating, dan controlling, terdapatnya kebijakan perpajakan yang jelas dan sederhana sehingga memudahkan wajib pajak untuk melaksanakan kewajibannya, tersedianya pegawai pajak yang berkualitas dan jujur serta pelaksanaan penegakan hukum yang tegas dan konsisten.

Zuhar (2002:6) mengemukakan bahwa reformasi administrasi didefiniskan sebagai the artificial inducement of administration transformation against resistance. Definisi ini mengandung beberapa implikasi, yaitu reformasi administrasi merupakan kegiatan yang dibuat oleh manusia (manmade) tidak bersifat eksidental, otomatis maupun alamiah; reformasi administrasi merupakan suatu proses; dan resistensi beriringan dengan proses reformasi administrasi. Sedangkan menurut Nasucha (2009:37), reformasi administrasi perpajakan adalah penyempurnaan atau perbaikan kinerja administrasi, baik secara individu, kelompok, maupun kelembagaan agar lebih efektif dan efisien. Agar reformasi administrasi perpajakan dapat berhasil maka dibutuhkan struktur pajak yang disederhanakan demi kemudahan dan kepatuhan. Selain itu strategi reformasi yang cocok harus dikembangkan, dan komitmen politik yang kuat terhadap peningkatan administrasi perpajakan. Sasaran reformasi administrasi pajak sendiri adalah meningkatkan kepatuhan para pembayar pajak dan melaksanakan ketentuan perpajakan secara seragam untuk penerimaan maksimal dengan biaya optimal.

Elemen dasar dalam reformasi administrasi perpajakan mempunyai beberapa syarat, yaitu komitmen politik yang berkelanjutan; staf yang mampu berkonsentrasi terhadap pekerjaan dalam jangka panjang; strategi yang tepat dan didefinisikan dengan baik karena tidak ada strategi yang cocok untuk semua negara; pendidikan dan pelatihan pegawai pajak; dan tersedia dana dan sumber daya lain yang cukup. Jika syarat-syarat tersebut terpenuhi maka reformasi administrasi perpajakan dapat berjalan dengan baik.

Nasucha (2009:68) menyatakan bahwa reformasi administrasi perpajakan dapat dilaksanakan tanpa melakukan reformasi perpajakan, yaitu untuk mensinergikan faktor internal dan eksternal yang mempengaruhi kinerja organisasi. Lingkungan eksternal 
yang dimaksud adalah kebijakan fiskal, yaitu item-item yang tidak dimasukkan dalam dasar pengenaan pajak, pembelanjaan dan pelayanan publik. Dalam ekonomi yang mulai berkembang, administrasi perpajakan harus difokuskan kepada wajib pajak besar secara maksimal dan memberikan kontribusi kepada wajib pajak kecil.

Mengingat lingkup dalam penelitian ini adalah analisis pengaruh proses pelaporan dan penyetoran pajak berpengaruh terhadap kepuasandan kepatuhan wajib pajak di KPP Pratama Sleman, maka kajian mengenai proses pelaporan dan penyetoran pajak terbatas pada proses pelaporan dan penyetoran pajak secara manual. Hal ini mengingat mayoritas wajib pajak yang berdomisili di KPP Pratama Sleman masih melakukan pengurusan pajak secara manual. Untuk melaporkan perhitungan dan penyetoran (pembayaran) pajak terutang, wajib pajak menggunakan sarana yang disebut SPT (Surat Pemberitahuan).

Ada dua jenis SPT yang digunakan untuk melaporkan perhitungan dan penyetoran pajak, yaitu (1). SPT Masa adalah SPT yang digunakan untuk melaporkan perhitungan dan penyetoran pajak terutang dalam suatu masa pajak atau pada suatu saat; (2). SPT Tahunan adalah SPT yang digunakan untuk melaporkan perhitungan dan penyetoran pajak dalam suatu tahun pajak.

Proses pelaporan pajak menggunakan SPT adalah sebagai berikut: wajib pajak harus mengambil sendiri blanko SPT di KPP Pratama Sleman dengan cara menunjukkan Nomor Pokok Wajib Pajak (NPWP). Selanjutnya, (1). SPT harus diisi dengan benar, jelas, dan lengkap sesuai dengan petunjuk yang

Tabel 1

Batas Waktu Penyampaian SPT Masa

\begin{tabular}{|c|c|c|}
\hline Jenis Pajak & Yang Menyampaikan SPT & $\begin{array}{c}\text { Batas Waktu Penyampaian } \\
\text { SPT Masa }\end{array}$ \\
\hline PPh Pasal 21 & Pemotong PPh Pasal 21 & $\begin{array}{l}\text { Tanggal } 20 \text { bulan takwim berikut- } \\
\text { nya setelah Masa Pajak berakhir. }\end{array}$ \\
\hline $\begin{array}{l}\text { PPh Pasal } 22 \text { Impor, PPN dan } \\
\text { PPnBM atas Impor }\end{array}$ & Wajib pajak & $\begin{array}{l}14 \text { hari setelah berakhirnya Masa } \\
\text { Pajak. }\end{array}$ \\
\hline $\begin{array}{l}\text { PPh Pasal } 22 \text { Impor, PPN dan } \\
\text { PPnBM atas Impor (Ditjen Bea } \\
\text { Cukai) }\end{array}$ & Direktorat Bea dan Cukai & $\begin{array}{l}7 \text { hari setelah batas waktu peny- } \\
\text { etoran berakhir. }\end{array}$ \\
\hline PPh Pasal 22Bendaharawan & Bendaharawan & $\begin{array}{l}14 \text { hari setelah berakhirnya Masa } \\
\text { Pajak. }\end{array}$ \\
\hline PPh Pasal 22Bahan Bakar & Pertamina & 20 hari setelah Masa Pajak berakhir. \\
\hline $\begin{array}{l}\text { PPh Pasal 22Pemungutan oleh } \\
\text { badan tertentu }\end{array}$ & Pemungut Pajak & 20 hari setelah Masa Pajak berakhir. \\
\hline PPh Pasal 23 & Pemotong PPh Pasal 23 & $\begin{array}{l}\text { Tanggal } 20 \text { bulan takwim berikut- } \\
\text { nya setelah Masa Pajak berakhir. }\end{array}$ \\
\hline PPh Pasal 25 & $\begin{array}{l}\text { Wajib pajak yang mempunyai } \\
\text { NPWP }\end{array}$ & $\begin{array}{l}\text { Tanggal } 20 \text { bulan takwim berikut- } \\
\text { nya setelah Masa Pajak berakhir. }\end{array}$ \\
\hline PPh Pasal 26 & Pemotong PPh Pasal 26 & $\begin{array}{l}\text { Tanggal } 20 \text { bulan takwim berikut- } \\
\text { nya setelah Masa Pajak berakhir. }\end{array}$ \\
\hline PPN dan PPnBM & Pengusaha Kena Pajak & $\begin{array}{l}\text { Tanggal } 20 \text { bulan takwim berikut- } \\
\text { nya setelah Masa Pajak berakhir. }\end{array}$ \\
\hline PPN dan PPnBM Pemungut & Pemungut PPN & $\begin{array}{l}20 \text { hari setelah bulan dilakukan } \\
\text { pembayaran atas tagihan. }\end{array}$ \\
\hline
\end{tabular}

(Sumber: Mardiasmo, 2012:28) 
Tabel 2

Batas Waktu Penyampaian SPT Tahunan

\begin{tabular}{lcl}
\multicolumn{1}{c}{ Jenis Pajak } & Yang Menyampaikan SPT & $\begin{array}{c}\text { Batas Waktu Penyampaian } \\
\text { SPT Masa }\end{array}$ \\
\hline SPT Tahunan PPh & Wajib pajak yang mempunyai NPWP & $\begin{array}{l}\text { Selambatnya } 3 \text { bulan setelah akhir Tahun Pajak } \\
\text { (biasanya tanggal 31 Maret tahun berikutnya). }\end{array}$ \\
PPh Pasal 21 Tahunan & Pemotong PPh Pasal 21 & Selambatnya 3 bulan setelah akhir Tahun Pajak. \\
\hline
\end{tabular}

(Sumber: Mardiasmo, 2012:29)

diberikan, kemudian ditandatangani. SPT yang tidak diisi dengan benar mengakibatkan pajak terutang kurang dibayar, sehingga akan dikenakan sanksi perpajakan. (2).Bagi wajib pajak badan, SPT harus ditandatangani oleh pengurus atau direksi. (3). Apabila SPT diisi dan ditandatangani oleh orang lain selain wajib pajak, harus melampirkan surat kuasa khusus. (4). SPT diserahkan kembali ke KPP bersangkutan dalam batas waktu yang ditentukan dan akan diberikan tanda terima tertanggal. Apabila SPT dikirim melalui pos harus dilakukan secara tercatat, tanda bukti serta tanggal pengiriman dianggap sebagai tanda bukti dan tanggal penerimaan (lihat tabel 1 dan tabel 2); (5). Pelaporan SPT harus disertai bukti-bukti yang dilampirkan, seperti (a). laporan keuangan berupa neraca dan laporan rugi laba serta keterangan-keterangan lain yang diperlukan untuk menghitung besarnya penghasilan kena pajak (bagi wajib pajak yang mengadakan pembukuan); (b).untuk SPT Masa PPN sekurang-kurangnya memuat jumlah Dasar Pengenaan Pajak, jumlah Pajak Keluaran, jumlah Pajak Masukan yang dapat dikreditkan, dan jumlah kekurangan atau kelebihan pajak; (c). perhitungan jumlah peredaran yang terjadi dalam tahun pajak yang bersangkutan (bagi wajib pajak yang menggunakan norma perhitungan).

Merujuk pada Peraturan Menteri Pendayagunaan Aparatur Negara Nomor 16 Tahun 2014 Tentang Pedoman Survei Kepuasan Masyarakat Terhadap Penyelenggaraan
Pelayanan Publik, titik berat pada prosedur pelayanan adalah mengenai kesederhanaan alur pelayanan.Wajib pajak menggunakan sarana penyetoran pajak yang disebut dengan SSP (Surat Setoran Pajak). Formulir SSP dapat diperoleh di KPP Pratama Sleman dan dapat diperbanyak (difotokopi) sendiri oleh wajib pajak. Tempat untuk menyetorkan pajak adalah bank-bank yang ditunjuk oleh Direktorat Jenderal Anggaran (bank persepsi) dan Kantor Pos dan Giro.

Kelima,teori kepuasan konsumen. Tjiptono (2012) mendefinisikan kepuasan konsumen sebagai suatu tanggapan emosional pada evaluasi pengalaman konsumen atas pelayanan yang diterima dari perusahaan. Kotler dkk.(2012) mendefinisikan kepuasan konsumen sebagai sejauh mana anggapan kinerja perusahaan memenuhi harapan konsumen. Bila kinerja layanan lebih rendah daripada harapan konsumen, maka konsumen tidak puas, bila kinerja sesuai atau melebihi harapan konsumen, maka konsumen merasa puas. Berdasarkan beberapa definisi kepuasan konsumen di atas dapat disimpulkan bahwa kepuasan akan tercapai pada saat harapan konsumen sesuai dengan kenyataan yang didapatkannya. Sedangkan kepuasan konsumen akan memperkuat sikap terhadap layanan dimana kemungkinan besar konsumen akan mengharapkan kembali layanan yang sama. Dewasa ini perhatian terhadap kepuasan wajib pajak telah semakin besar. Semakin banyak pihak yang menaruh 
perhatian terhadap hal ini. Pihak yang paling banyak berhubungan langsung dengan kepuasan atau ketidakpuasan wajib pajak adalah kantor pelayanan pajak. Tuntutan pemenuhan kebutuhan dan keinginan wajib pajak menyebabkan setiap kantor pelayanan pajak harus menempatkan orientasi pada kepuasan wajib pajak sebagai tujuan utama. Hal ini tercermin dari semakin banyaknya kantor pelayanan pajak yang menyertakan komitmennya terhadap kepuasan wajib pajakdalam pernyataan visi dan misinya, iklan, maupun public relations release. Dewasa ini diyakini bahwakunci utama untuk memenangkan persaingan adalah memberikan nilai dan kepuasan kepada konsumen atau melalui penyampaian produk layanan berkualitas dengan tarif bersaing. Dari definisi kepuasan konsumen di atas dapat ditarik kesimpulan bahwa pada dasarnya kepuasan konsumen merupakan suatu hal yang prinsipil yang harus dipenuhi oleh perusahaan dalam proses mempertahankan konsumen dan membentuk loyalitas pelanggan pada produk maupun jasa yang dijual oleh perusahaan. Dalam mengevaluasi kepuasan konsumen, umumnya perusahaan mengacu pada berbagai faktor atau dimensi. Faktor yang sering digunakan dalam mengevaluasi keputusan terhadap suatu produk layanan, menurut Tjiptono (2012) meliputi: kinerja (performance), ciri-ciri atau keistimewaan tambahan (features), keandalan (reliability), kesesuaian dengan spesifikasi (conformance to specifications), daya tahan (durability), servicebility, estetika, kualitas yang dipersepsikan (perceived quality). Sedangkan untuk mengevaluasi jasa yang bersifat intangibles, wajib konsumen (wajib pajak) umumnya menggunakan beberapa atribut atau faktor yang lebih dikenal dengan kualitas pelayanan yang terdiri dari bukti langsung (tangibles), kehandalan (reliability), daya tanggap (responsiveness), jaminan (assurance), perhatian (empathy).

Merujuk pada Peraturan Menteri Pendayagunaan Aparatur Negara No.16 Tahun 2014 Tentang Pedoman Survei Kepuasan Masyarakat Terhadap Penyelenggaraan Pelayanan Publik, dijelaskan bahwa terdapat 9 (sembilan) unsur yang relevan, valid, dan reliabel, sebagai dasar pengukuran survei kepuasan masyarakat. Kesembilan unsur tersebut adalah persyaratan, prosedur, waktu pelayanan, biaya/tarif, produk spesifikasi jenis pelayanan, kompetensi pelaksana, perilaku pelaksana, maklumat pelayanan, penanganan pengaduan, saran dan masukan. Persyaratan adalah syarat yang harus dipenuhi dalam pengurusan suatu jenis pelayanan, baik persyaratan teknis maupun administratif. Prosedur adalah tata cara pelayanan yang dibakukan bagi pemberi dan penerima pelayanan, termasuk pengaduan. Waktu pelayanan adalah jangka waktu yang diperlukan untuk menyelesaikan seluruh proses pelayanan dari setiap jenis pelayanan. Biaya/ tarif adalah ongkos yang dikenakan kepada penerima layanan dalam mengurus dan/atau memperoleh pelayanan dari penyelenggara yang besarnya ditetapkan berdasarkan kesepakatan antara penyelenggara dan masyarakat. Produk spesifikasi jenis pelayanan adalah hasil pelayanan yang diberikan dan diterima sesuai dengan ketentuan yang telah ditetapkan. Produk pelayanan ini merupakan hasil dari setiap spesifikasi jenis pelayanan. Kompetensi Pelaksana adalah kemampuan yang harus dimiliki oleh pelaksana meliputi pengetahuan, keahlian, keterampilan, dan pengalaman. Perilaku Pelaksana adalah sikap petugas dalam memberikan pelayanan. Maklumat Pelayanan adalah merupakan 
Gambar 1

Kualitas Pelayanan dan Kepatuhan Wajib Pajak

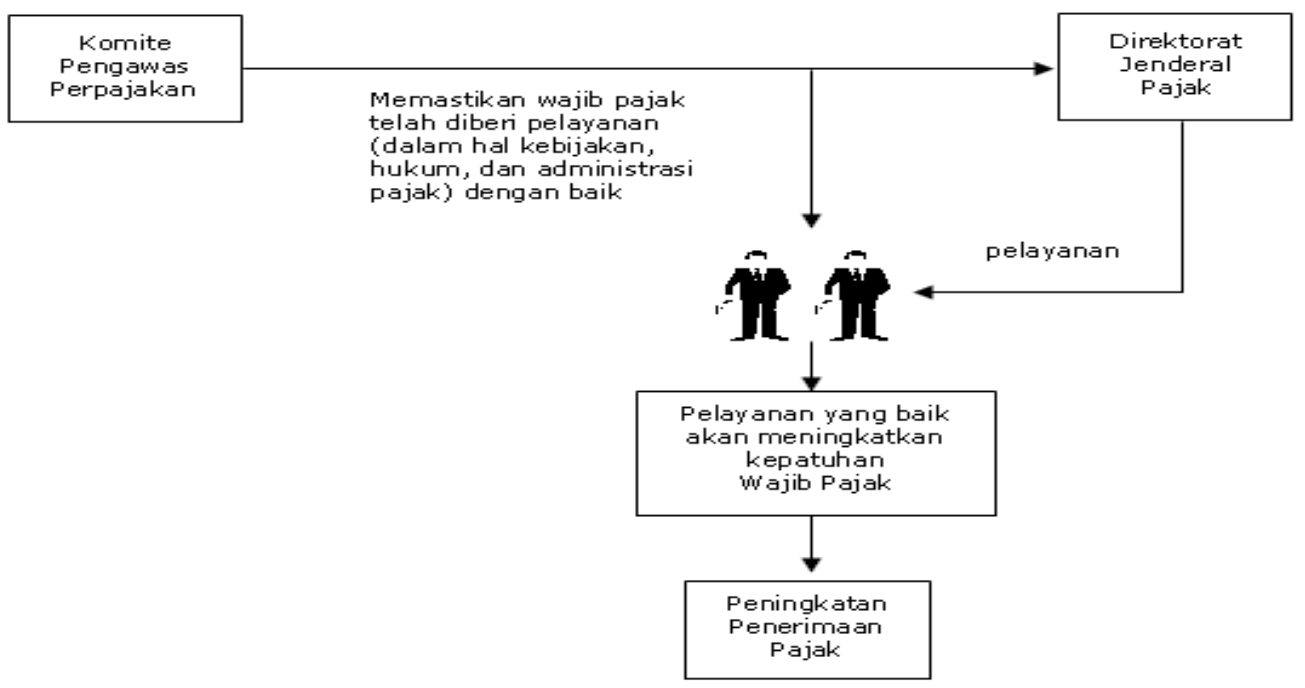

(Sumber: Surjoputro dkk., 2009:32-35)

pernyataan kesanggupan dan kewajiban penyelenggara untuk melaksanakan pelayanan sesuai dengan standar pelayanan. Penanganan pengaduan, saran dan masukan, adalah tata cara pelaksanaan penanganan pengaduan dan tindak lanjut.

Keenam,teori kepatuhan (perpajakan). Nurmantu(2008:148)mendefinisikan kepatuhan perpajakan sebagai suatu keadaan dimana wajib pajak memenuhi semua kewajiban perpajakan dan melaksanakan hak perpajakannya. Sedangkan Nasucha (2009:9) kepatuhan wajib pajak dapat diidentifikasi dari ketaatan wajib pajak dalam memenuhi persyaratan, mendaftarkan diri, dan kepatuhan untuk mengembalikansurat pemberitahuan (SPT) yang sudah diisi lengkap, kepatuhan mengisi lengkap surat setoran pajak (SSP), kepatuhan dalam penghitungan dan pembayaran pajak terutang, dan kepatuhan dalam pembayaran tunggakan (lihat gambar 1).

Besarnya jurang kepatuhan, yaitu selisih antara penerimaan yang sesungguhnya dengan pajak potensial dengan tingkat kepatuhan dari masing-masing sektor perpajakan merupakan pengukuran yang lebih akurat atas administrasi perpajakan. Keberhasilan pengumpulan pajak hanyalah merupakan akibat semakin sempitnya jurang kepatuhan. Semakin patuh rakyat membayar pajak berarti jurang kepatuhan semakin sempit dan berarti pemungutan pajak lebih berhasil. Sebaliknya, semakin lebar jurang kepatuhan maka semakin sedikit pajak yang berhasil dikumpulkan. Kepatuhan wajib pajak telah diupayakan dengan mengubah sistem administrasi perpajakan. Menurut Surjoputro dkk. (2009:32-35), pada hakikatnya kepatuhan wajib pajak dipengaruhi oleh kondisi sistem administrasi perpajakan yang meliputi tax service dan tax enforcement. Langkah-langkah perbaikan administrasi diharapkan dapat mendorong kepatuhan wajib pajak melalui dua cara, yaitu (a).wajib pajak patuh karena mendapatkan pelayanan yang baik, cepat, dan memuaskan, serta pajak yang mereka bayar akan bermanfaat bagi pembangunan bangsa; (b).wajib pajak akan patuh karena mereka berpikir bahwa mereka akan mendapat sanksi berat akibat pajak yang tidak mereka 
laporkan terdeteksi sistem informasi dan administrasi perpajakan serta kemampuan crosschecking informasi dengan instansi lain. Ketika sistem perpajakan suatu negara telah maju, pendekatan reformasi diletakkan pada peningkatan dalam kepuasan, kepatuhan, dan administrasi perpajakan. Peningkatan kepuasan dan kepatuhan wajib pajak sangat penting dalam reformasi perpajakan, dan mungkin lebih penting daripada perubahan struktural dalam sistem perpajakan.

Analisis data dalam penelitian ini menggunakan Structure Equation Modeling (SEM) dengan bantuan program komputer AMOS (Analysis of Moment Structur) versi 22.0. Program AMOS v22.0 merupakan program statistik terpopuler dan lebih baik daripada program-program statistik yang lain seperti SmartPLS v3.0; Lisrel 8.80; SPSS v23; Minitab 12.0 dan lain-lain (Ghozali, 2014). SEM merupakan gabungan dari dua metode statistik yang terpisah, yaitu analisis faktor (faktor analysis) yang dikembangkan di ilmu statistik serta model persamaan simultan (simultaneous equation modeling) yang dikembangkan di ekonometrika (Ghozali, 2014). Model SEM merupakan gabungan dari analisis faktor dan analisis jalur (path analysis) menjadi satu metode statistik komprehensif. Seperti yang dinyatakan Joreskog (1973) dalam Ghozali (2014), model persamaan struktural umum terdiri dari dua bagian, yaitu (a). bagian pengukuran, yang menghubungkan observed variable ke latent variable melalui confirmatory faktor model; (b). bagianstructural, yang menghubungkan antar latent variable melalui persamaan regresi simultan.

SEM memiliki keunggulan dibandingkan dengan metode statistic multivariate yang lain karena dalam variabel laten dimasukkan kesalahan pengukuran dalam model. SEM memasukkan struktural error term untuk mencapai konsistensi estimasi parameter, error term ini diasumsikan tidak berkolerasi dengan konstruk eksogen dalam model, namun demikian struktural error term dapat berkolerasi dengan struktural error term lain dalam model. Menurut Ghozali (2014), dalam penelitian SEM yang pertama diindentifikasi adalah teori. Bila ada teorinya, maka teori tersebut harus diungkapkan lebih dahulu. SEM digambarkan oleh diagram jalur, dipandang sebagai representasi dari teori. Jadi hubungan antara variabel laten yang diwujudkan dalam diagram jalur merupakan perwujudan dari teori. Kemudian didapatkan sampel dan pengukurannya, setelah itu dapat dilakukan estimasi terhadap parameter model.Pada tahap ini pengukuran model dapat diestimasi lebih dahulu dan diikuti dengan model struktural atau full model. Kemudian melakukan penilaian goodness fit dari model dan bilamana diperlukan diikuti dengan modifikasi model. Jika model telah memenuhi kriteria fit, maka dilakukan diskusi atau pembahasan hasil.

Penelitian ini menggunakan variabel laten dan variabel manifest. Variabel laten atau konstruk, yaitu variabel yang tidak dapat diukur secara langsung (unobserved). Keberadaan variabel laten diukur oleh indikator-indikator atau variabel manifes. Responden dalam penelitian diminta untuk menjawab pertanyaan dalam bentuk skala Likert. Dalam penelitian ini ada 4 (empat) variabel laten yang diukur, terdiri 2 (dua) variabel laten eksogen $(\xi)$, yaituproses pelaporan dan penyetoran pajak, dan 2 (dua) variabel laten endogen $(\eta)$, yaitu kepuasan dan kepatuhan wajib pajak. Setiap variabel laten akan diukur oleh variabel manifes. Variabel manifes ini merupakan butir-butir kuesioner masingmasing variabel laten. 
Penelitian ini juga menegaskan kriteria goodness-of-fit (kelayakan). Sebelum menilai kelayakan dari SEM harus dilakukan penilaian terhadap data yang akan diolah memenuhi asumsi SEM. Ada tiga asumsi dasar yang harus dipenuhi untuk dapat menggunakan SEM, yaitu observasi data independen, responden diambil secara acak (random sampling respondent), dan memiliki hubungan linear.

Goodness-of-Fit mengukur kesesuaian input observasi atau sesungguhnya (Matrik kovarian atau korelasi) dengan prediksi dari model yang diajukan (proposed model) (Ghozali, 2014). Kriteria goodness-of-fit, meliputi (1). Likelihood-Ratio Chi-Square Statistic. Nilai Chi-square yang tinggi relatif terhadap degree of freedom menunjukkan bahwa matrik kovarian atau korelasi yang diobservasi dengan yang diprediksi berbeda secara nyata dan ini menghasilkan probabilitas (p) lebih kecil dari tingkat signifikansi $(\alpha)$. Nilai chi-square yang kecil akan menghasilkan nilai probabilitas (p) yang lebih besar dari tingkat signifikansi $(\alpha)$, hal ini menunjukkan bahwa input matrik kovarian antara prediksi dengan observasi sesungguhnya tidak berbeda secara signifikan. (2). CMIN. Chi-square $\left(\chi^{2}\right)$ merupakan metode paling umum dalam mengevaluasi goodness-of-fit.Kecilnya nilai $\chi^{2}$ mengindikasikan tidak signifikan dan menjadi tanda kesesuaian yang baik.Pengujian Chi-square digunakan untuk menilai matrik aktual dan prediksi. Tidak signifikan berarti adanya perbedaan antara matrik aktual dengan prediksi (Hair dkk., 1998 dalam Ferdinand, 2015). (3). CMIN/DF, merupakan nilai Chisquare dibagi dengan degree of freedom. Jika nilai ratio ini $<2$ merupakan ukuran yang fit. (4). GFI. Goodness of fit index (GFI) merupakan ukuran non-statistik yang nilainya berkisar dari 0 (poor fit) sampai 1.0 (perfect fit). (5). RMSEA. Root mean square error of approximation (RMSEA) merupakan ukuran yang mencoba memperbaiki kecenderungan statistik chi-square menolak model dengan jumlah sampel yang besar.Nilai RMSEA antara 0.05 sampai 0.08 merupakan ukuran yang dapat diterima. (6). AGFI. Adjusted goodnessof-fit (AGFI) merupakan pengembangan dari GFI yang disesuaikan dengan ratio degree of freedom untuk proposed model dengan degree of freedom untuk null model. Nilai $\geq_{0.80}$ merupakan nilai yang dapat diterima. (7). TLI. Tucker Lewis Index (TLI) atau dikenal dengan nonnormed fit index (NNFI) merupakan penggabungan ukuran parsimony ke dalam index komparasi antara proposed modeldan

Tabel 3

Evaluasi Kriteria Goodness-of-Fit

\begin{tabular}{clc}
\hline No & \multicolumn{1}{c}{ Kriteria } & Cut of Value \\
\hline 1 & Chi-square & $\leq \chi^{2}$-table $(\mathrm{df} ; 5 \%)$ \\
2 & $\chi^{2}$ significance probability & $\geq 0.05$ \\
3 & Relative $\chi^{2}$ (CMIN/DF) & $\leq 2,00$ \\
4 & GFI (Goodness of Fit) & $\geq 0.90$ \\
5 & AGFI (Adjust Goodness of Fit Index) & $\geq 0.80$ \\
6 & TLI (Tucker-Lewis Index) & $\geq 0.90$ \\
7 & NFI (Normated Fit Index) & $\geq 0.80$ \\
8 & CFI (Comparative Fit Index) & $\geq 0.90$ \\
9 & RMSEA (Root Mean Square error of Approximation) & $\leq 0.08$ \\
\hline
\end{tabular}

(Sumber: Ferdinand, 2015; Ghozali, 2014; Wijaya, 2009) 
Gambar 2

Kerangka Konsep: Model Penelitian dengan Variabel Mediasi Kepuasan Wajib Pajak

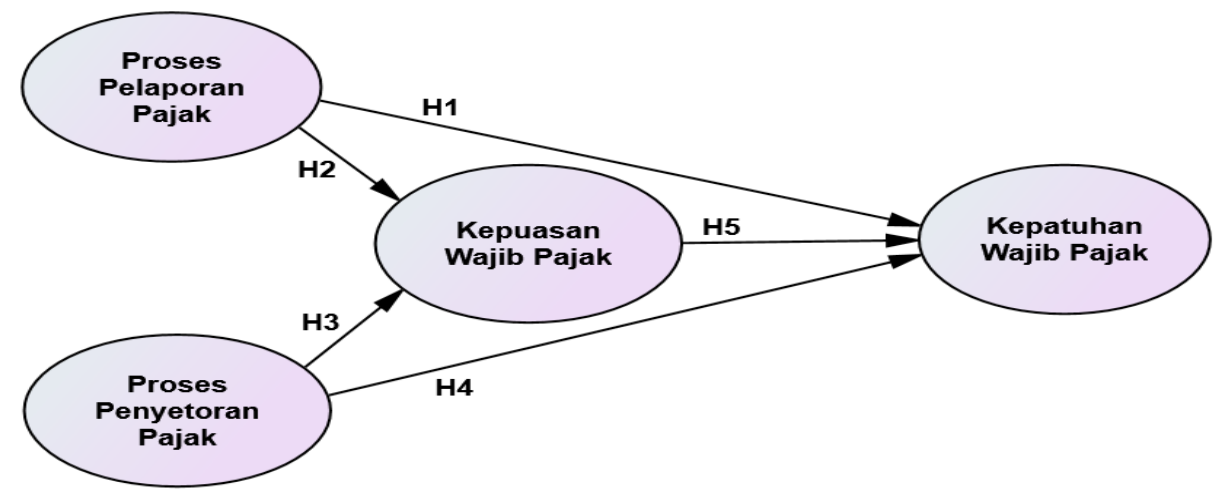

(Sumber: Data sekunder yang diolah)

null model. Nilai TLI yang direkomendasikan adalah $\geq 0.90$.

Evaluasi kriteria goodness-of-fit dalam penelitian ini dapat dilihat dalam tabel 3.

Dari 9 (sembilan) unsur survei kepuasan masyarakat, sesuai Keputusan Menteri Pendayagunaan Aparatur Negara No.16 Tahun 2014, yaitu persyaratan, prosedur, waktu pelayanan, biaya/tarif, produk spesifikasi jenis pelayanan, kompetensi pelaksana, perilaku pelaksana, maklumat pelayanan, penanganan pengaduan, saran dan masukan, tercakup unsur prosedur pembayaran pajak yang diurai menjadi 2 (dua) faktor, yaitu proses pelaporan dan penyetoran pajak. Kedua faktor tersebut turut menjadi unsur prosedur pembayaran pajak yang merupakan penyusun survei kepuasan masyarakat atau dapat dituliskan bahwa faktor-faktor proses pelaporan dan penyetoran pajak berpengaruh terhadap kepuasan pengguna pelayanan KPP Pratama Sleman.

Untuk menunjukkan adanya pengaruh variabel independen terhadap variabel dependen, dikembangkan sebuah model penelitian. Penelitian ini menggunakan satu variabel dependen (yaitu kepatuhan wajib pajak), dua variabel independen (yaitu proses pelaporan dan penyetoran pajak), dan 1 variabel mediasi (yaitu kepuasan wajib pajak), maka digunakan model persamaan terstruktur (SEM) dari program statistik AMOS v22.0 sebagaimana ditunjukkan pada gambar 2 .

Variabel mediasi yang sering disebut sebagai variabel interveningadalah variabel yang secara teoritis dapat mempengaruhi hubungan kausal antara variabel independen terhadap variabel dependen. Variabel ini terletak antara variabel independen dan variabel dependen, sehingga variabel independen tidak secara langsung mempengaruhi variabel dependen.Variabel mediasi berbeda dengan variabel moderasi atau moderating (Ghozali, 2014).

Variabel mediasi yang digunakan dalam penelitian ini adalah kepuasan wajib pajak, sebab kepuasan wajib pajak dipengaruhi oleh proses pelaporan dan penyetoran pajak dan sekaligus kepuasan wajib pajak mempengaruhi kepatuhan wajib pajak. Dalam hal ini variabel kepuasan wajib pajak menjadi variabel antara atau mediasi atau intervening (Surjoputro dkk., 2009; Gunadi, 2009). Variabel moderasi (moderating) adalah variabel yang mampu memperkuat atau memperlemah hubungan kausal antara variabel independen terhadap 
variabel dependen. Variabel moderasi tidak bisa digunakan dalam model persamaan terstruktur (SEM) (Ghozali, 2014).

\section{PEMBAHASAN}

\section{Gambaran Umum Lokasi Penelitian}

Lokasi penelitian dilakukan di Kabupaten Sleman, yaitu di area persebaran masyarakat wajib pajak yang pernah dilayani KPP Pratama Sleman. Penelitian dilakukan pada bulan Oktober sampai dengan Desember 2017. Pemilihan Kabupaten Sleman didasarkan pada tingginya kepatuhan wajib pajak sekitar 91\% dari 37.530 SPT (2016). Angka 91\% ini merupakan angka tertinggi di Provinsi Daerah Istimewa Yogyakarta pada tahun 2016.

\section{Karakteristik Demografi Responden}

Analisis deskriptif ini didasarkan pada data penelitian yang telah terkumpul, berupa hasil tanggapan kuesioner yang diperoleh dari 144 responden wajib pajak orang pribadi. Data penelitian yang terkumpul tersebut ditransformasikan dalam bentuk tabel numerik sehingga mudah dipahami dan diinterprestasikan. Analisis deskriptif digunakan peneliti untuk memberikan informasi mengenai karakteristik demografi responden.

Pertama, berdasarkan jenis kelamin. Dapat diketahui dari 144 responden wajib pajak orang pribadi yang berjenis kelamin laki-laki sebanyak 81 orang atau 56,25\%, sedangkan untuk responden wajib pajak orang pribadi dengan jenis kelamin perempuan sebanyak 63 orangatau 43,75\%. Jumlah tersebut menunjukkan bahwa mayoritas wajib pajak orang pribadi yang menjadi ukuran sampel dalam penelitian ini adalah laki-laki.

Kedua,berdasarkan usia.Usia seseorang merupakan faktor yang dapat menentukan sikap dalam memberikan penilaian terhadap sesuatu hal baik berupa produk maupun jasa yang dikarenakan oleh pengetahuan, pandangan, pengalaman dan keyakinan yang berbeda, sehingga akan mepengaruhi penilaiannya. Dapat diketahui dari 144 responden wajib pajak orang pribadi yang mempunyai usia 18-24 tahun sebanyak 9 orang atau 6,25\%, usia 25-35 tahun sebanyak 43 orang atau $29,86 \%$, usia 36-45 tahun sebanyak 66 orang atau $45,83 \%$ dan di atas 45 tahun sebanyak 26 orang atau 18,06\%. Dari jumlah tersebut menunjukkan bahwa mayoritas wajib pajak orang pribadi adalah usia 36-45 tahun.

Ketiga,berdasarkan pekerjaan.Pekerjaan merupakan faktor yang dapat menentukan sikap wajib pajak orang pribadi dalam memilih produk dan jasa pada khususnya pada pemilihan tempat untuk menginvestasikan sebagian penghasilannya. Hal ini disebabkan karena pekerjaan secara langsung maupun tidak langsung akan berhubungan dengan tingkat penghasilan dalam menggunakan suatu produk atau jasa. Dari 144 responden wajib pajak orang pribadi yang menjadi ukuran sampel yaitu wajib pajak orang pribadi di Kabupaten Sleman menunjukkan bahwa tingkat pekerjaan responden mayoritas adalah pegawai swasta yaitu sebanyak 84 orang atau $58,33 \%$, sedangkan pekerjaan lain yaitu mahasiswa sebanyak 9 orang atau $6,25 \%$, pegawai negeri sebanyak 29 orang atau $20,14 \%$, dan pekerjaan lain-lain sebanyak 22 orang atau 15,28\%. Dari jumlah tersebut menunjukkan bahwa mayoritas wajib pajak orang pribadi di Kabupaten Sleman adalah pegawai swasta.

Keempat, berdasarkan penghasilan. Tingkat penghasilan yang diterima seorang wajib pajak orang pribadi dapat memberikan penilaian dan persepsi layanan yang berbeda 
pada sesuatu hal yang dilihatnya. Dengan penghasilan yang berbeda-beda ini, penilaian yang diberikan wajib pajak orang pribadi diharapkan obyektif. Dari 144responden wajib pajak orang pribadi yang menjadi ukuran sampel menunjukkan bahwa rata-rata pengahasilan responden wajib pajak orang pribadi di bawahRp. 2.500,000 sebanyak 33 orang atau $22,92 \%$, penghasilan $\mathrm{Rp}$ $2.500,000$ - Rp. 5.000,000 sebanyak 69 orang atau 47,92\%, penghasilan Rp. 5.000,000-Rp $10.000,000$ sebanyak 29 orang atau $20,14 \%$ dan penghasilan di atasRp. 10.000,000 sebanyak 13 orangatau 9,03\%. Dengan demikian dari sampel yang diambil menunjukkan bahwa mayoritas wajib pajak orang pribadi mempunyai penghasilan antara Rp.2.500,000Rp. 5.000,000.

Penelitian survei dengan sampel masyarakat dengan berpajak di wilayah Sleman (Cooper, 2006). Data pilot project dan data survey dijabarkan dalam cacatan angka dengan menggunakan metode deskriptif dan (SEM). Instrumen penelitian yang digunakan adalah kuesioner, yaitu suatu pernyataan yang disusun dan diajukan kepada responden untuk dijawab dan dinilai. Kuesioner yang disusun terdiri dari 4 jawaban (STS, TS, S, SS),

Hasil pengujian mendapatkan beberapa kriteria goodness fit index, salah satu yang merupakan kriteria absolute adalah Chisquare sebesar 177,445, nilai ini kurang dari $\chi^{2}$-tabel pada df 524 kepercayaan 95\% sebesar 215,563, berarti terdapat perbedaan atau tidak memiliki kesesuian antara kovarian sampel dengan kovarian yang diestimasi, ketidaksesuaian ini menunjukkan kurangnya dukungan dari sampel untuk menjelaskan estimasi (populasi) (Ghozali, 2014:748).

Selain Chi-square, diperoleh juga hasil kesesuian lainnya, yang kesemuanya memenuhi syarat atau Cut of Value yang direkomendasikan. Dari hasil pengukuran Goodness Fit Index besarnya Chi Square, CMIN /DF, CFI, AGFI, GFI, RMSEA,TLI diperoleh nilai yang telah memenuhi kriteria. Tampak bahwa tingkat probabilitas adalahsignifikan yaitu sebesar 0,602 ( $\mathrm{p} \leq$ $0,05)$ sehingga model yang dianalisis mampu memenuhi kriteria model yang baik.

Penelitian ini sesuai dengan temuan Akintoye (2013) yang menjelaskan bahwa kepatuhan melalui kesediaan melunasi pajak sangat utama dan tidak dapat dilupakan. Pemerintah harusmemperhatikan faktor yang mempengaruhi, layanan proses pelaporan pajak; dapat meningkatkan pendapatan pemerintah serta pertumbuhan ekonomi. Penelitian oleh Moeinadin (2014), faktor sosial, individu, struktural, hukum, dan layanan dapat mempengaruhi proses pelaporan pajak. Proses pelaporan pajak berfungsi meningkatkan kepatuhan pajak. Adapun upaya pembentukan layanan proses pelaporan pajak yang berkualitas.

Mavengere (2015) menyatakan bahwa norma pribadi dan pelayanan proses pelaporan merupakan kontributor pendukung terhadap kepuasan wajib pajak, dengan semakin meningkatnya kualitas layanan pajak pun akan meningkat.Jayawardane (2016) menyebutkan kemungkinan para pembuat kebijakan untuk menerapkan strategi yang cocok guna meningkatkan penerimaan pajak pemerintah dengan memberikan layanan yang optimal untuk pelaku pajak. Stakeholder theory (Fountaine, 2006) membantu tercapainya keunggulan kompetitif serta meminimalkan kerugian kepatuhan pajak dengan mengelola dan memanfaatkan fasilitas unit layanan pajak dengan baik untuk menciptakan kepuasan, ketaatan dalam membayar pajak, dimana hal 
ini dilakukan untuk kepentingan masyarakat (Mardiasmo, 2012).

Penelitian ini seiring sejalan dengan Helhel (2015) bahwa faktor internal dalam penyetoran pajak merupakan penentu yang efektif dibanding faktor eksternal. Kemampuan untuk membayar pajak, pembayaran pajak dengan akurat, meningkatkan semangat pajak dan kesadaran warga, dan penilaian ulang kebijakan pencegahan seperti pembebasan, audit, hukuman dan denda telah dianggap sebagai faktor penting. Penelitian ini juga menemukan tidak ada perbedaan yang efektif secara statistik dalam persepsi dan sikap responden terhadap penyetoran pajak sesuai dengan usia dan lokasi perusahaan, namun memiliki perbedaan sesuai dengan kepemilikan dan subsektor UKM. Hasil penelitian Nkwe (2013) pun menyebutkan bahwa sikap pelaku pajak dalam memproses penyetoran pajak juga mempengaruhi perilaku kepatuhannya pajak.

Abdul-Razak (2013) menyatakan bahwa tagihan pajak akan mempengaruhi sikap kepuasan individu, tingkat keterbukaan pemerintah tidak secara signifikan mempengaruhi sikap para pembayar pajak, hubungan antara pemahaman dan keputusan kepatuhan pajak; dan sesuai hasil penelitian Akintoye (2013) yang menyatakan melalui kesediaan warga dalam taat pajak tidak dapat diabaikan; pemerintah harus memperhatikan faktor yang akan mempengaruhi kesediaan dan kepuasan dalam membayar pajak; dengan demikian mampu mengoptimalkan pendapatan pemerintah serta mampu meningkatkan ketahanan ekonomi.Proses penyetoran pajak didasarkan pada agency theory (Chen, 2005; dan Arifin, 2005) yakin unit layanan pajakakan memberikan kepuasan bagi mereka, yakin bahwa tidak akan pengecewakan pelaku wajib pajak (Meverenge, 2015; dan Abdul-Razak, 2013).

Moeinadin (2014) menunjukkan bahwakepatuhan wajib pajak dipengaruhi oleh sosial, individu, struktural, hukum; hasil ini seiring sejalan dengan Panayiotis (2014) menyatakan bahwa efektivitas pemerintah untuk mengumpulkan pajak meningkatkan fasilitas publik, tetapi tidak menjamin maksimalisasi yang tergantung pada pengeluaran pemerintah. Jika pemerintah tidak maksimal dalam melakukan audit, kesejahteraan dari penyediaan fasilitas publik menjadi tunduk norma-norma sosial yang diantaranya adalah pengetahuan, kesadaran hukum, dan kepuasan para wajib pajak. Korir (2015) menemukan bahwa prediktor signifikan bagi kepatuhan wajib pajak; kompleksitas, keadilan, penyesuaian biaya. Penelitian ini merekomendasikan pengurangan ekuitas dan peningkatan kepuasan wajib pajak. Penelitian lanjutan diperlukan dalam menilai efektivitas kompleksitas, keadilan, penyesuaian biaya, dan tindakan kebijakan, dalam menentukan kepatuhan wajib pajak. Pendekatan resource based theory(Barney, 2007) fasilitas yang dipunyai cabang layanan pajak berpengaruh terhadap kinerja,hal tersebut akan meningkatkan kepuasan wajib pajak, dimana kepuasan wajib pajak ini merupakan persyaratan utama bagi kepatuhan pajak (Surjoputro, 2009; dan Gunadi, 2009). Membandingkan nilainilai Sobel (Z), maka pengaruh variabel proses penyetoran pajak terhadap variabel kepatuhan wajib pajak ternyata lebih kuat, yaitu sebesar 6,204, pengaruh variabel proses pelaporan pajak terhadap variabel kepatuhan wajib pajak, yaitu sebesar 3,188, dengan variabel mediasi yang sama. 


\section{Implikasinya Terhadap Ketahanan Ekonomi Wilayah}

Ketahanan ekonomi merupakan kondisi kehidupan perekonomian bangsa yang berlandaskan pada demokrasi Pancasila (Tarmini, 1992). Ketahanan ekonomi juga mengandung kemampuan untuk memelihara stabilitas ekonomi yang sehat dan dinamis, serta mampu menciptakan kemandirian ekonomi nasional dengan daya saingyang tinggi sehingga kemakmuran rakyat yang adil dan merata dapat terwujud. Proses pelaporan pajak ternyata berpengaruh lebih banyak dibandingkan dengan proses penyetoran pajak, sehingga masyarakat lebih puas dan lebih patuh, maka perwakilan pelayanan pajak Sleman dapat menaikkan mutu pelayanan di bidang pelaporan pajak.

\section{SIMPULAN}

Dari penjelasan tersebut diatas dapat ditarik simpulan sebagai berikut.

Pertama, proses pelaporan dan penyetoran pajak berpengaruh positif terhadap kepuasan dan kepatuhan wajib pajak, hal tersebut juga akan memberikan dampak yang positif terhadap ketahanan ekonomi wilayah tersebut.

Kedua, pelayanan yang memuaskan pada kantor pelayanan pajak juga berpengaruh terhadap tinggat pelaporan dan penyetoran pajak, semakin optimal pelayanan yang diberikan kepada wajib pajak maka semakin rendah tingkat ketidakpatuhan terhadap wajib pajak, begitu sebaliknya.

Selanjutnya, direkomendasikan hal-hal sebagai berikut.

Pertama, proses pelaporan pajak ternyata berpengaruh lebih lemah dibandingkan dengan proses penyetoran pajak, sehingga agar para wajib pajak lebih puas dan lebih patuh, maka kantor pelayanan pajak di Kabupaten Sleman dapat meningkatkan kualitas pelayanan di bidang pelaporan pajak

Kedua, pemerintahdiharapkan melaksanan program peningkatan kualitas layanan pajak di Kabupaten Sleman. Hal ini dapat dilakukan mulai dari yang sederhana dan tidak memerlukan biaya tinggi, seperti program layanan terpadu sampai kepada pembenahan manajemen yang mengatur layanan cepat, efektif dan efisien

Ketiga, pemerintah diharapkan dapat menentukan tingkat kualitas layanan dan kepuasan wajib pajak yang lebih baik di tahun tahun berikutnya. Prinsipnya kualitas layanan dan kepuasan wajib pajak orang pribadi harus mulai menjadi bagian yang dikelola, bukan dibiarkan tumbuh dengan sendirinya

Keempat, untuk ke depannya pemerintah diharapkan lebih banyak melakukan penyuluhan dan sosialisasi pajak kepada masyarakat agar para wajib pajak yang tidak patuh semakin berkurang dan jumlah total para wajib pajak semakin meningkat.

\section{DAFTAR PUSTAKA}

Abdul-Razak, A Dan Adafula, CJ. 2013. Evaluating taxpayers' attitude and its influence on tax compliance decisions in Tamale, Ghana. Journal of Accounting and Taxation Vol. 5(3), pp. 48-57, September 2013 DOI: 10.5897/JAT2013.0120 ISSN 2141-6664 (C) 2013 Academic Journals http://www.academicjournals.org/JAT

Akintoye, I.R Dan Tashie, G.A. 2013. The Effect of Tax Compliance on Economic Growth and Development in Nigeria, West-Africa. British Journal of Arts and Social Sciences. ISSN: 2046-9578, Vol.11 No. II (2013). CBritish Journal Publishing, Inc. 2013. http://www.bjournal.co.uk/ BJASS.aspx 
Alfioza, K Dan A. Silfi. 2011. Signalling. Theory: A Review and Assessment. Journal of Management. Vol. 37, No. 1. Hal. 39-67

Arifin. 2005. Tinjauan Perspektif Teori Keagenan (Agency Theory).Pidato Pengusulan Jabatan Guru Besar. Universitas Diponegoro. Semarang.

Barney, J.B. Dan Clarck, D.N. 2007. Resourced Based Theory: Creating and Sustaining Competitive Advantage. Princeton: Oxford University Press

Barney, Jay B. 2001. Is the Resource-Based Theory a Useful Perspective for Strategic Management Research? Yes. Academy of Management Review. 26 (1): 41-56.

Cooper, D.R. dan Schindler,P.S, 2006. Business Research Methods, New York: McGrawHill Companies, Inc.

Chen, A dan Kao, L. 2005. The Conflict between Agency Theory and Corporate Control on Managerial Ownership: The Evidence from Taiwan IPO Performance.

Ferdinand, A., 2015. Structural Equation Modeling Dalam Penelitian Manajmen, Semarang: FE-UNDIP

Fountaine, C., Haarman, A., dan Schmid, S., 2006. Stakeholder Theory of The MNC, Princeton: Oxford University Press.

Freeman, RE., 2004. A Stakeholder Theory of Modern Corporations: Ethical Theory and Business, $7^{\text {th }}$ ed.

Ghozali, I, 2014. Model Persamaan Struktural: Konsep dan Aplikasi Dengan Program AMOS v22, Semarang: FE-UNDIP

Gunadi. 2009. Rasionalitas Reformasi Administrasi Perpajakan. Jakarta: Fakultas Ekonomi Universitas Indonesia.

Helhel, Y. Dan Varshalomidze, M. 2015. Determinants of Tax Attitude and Tax
Compliance among Small and Medium Enterprises (SMEs) in Tourism Industry: A Survey Study in Georgia. Archives of Business Research Vol.3, No.5. Publication Date: Oct. 25, 2015 DOI: 10.14738/ abr.35.1495.

Jayawardane, Damayanthi Dan Low, K. 2016. Taxpayer Attitude and Tax Compliance Decision in Sri Lanka. How the Taxpayers' Attitudes influence Tax Compliance Decision among individual Taxpayers in Colombo City in Colombo District. International Journal of Arts and Commerce ISSN 1929-7106 www. ijac.org.uk

Keban, Y.T. 2009. Enam Dimensi Strategis Administrasi Publik: Konsep, Teori dan Isu. Yogyakarta: Penerbit Gava Media.

Kotler, P dan Keller, KP, 2012. Marketing Management, Harlow: Pearson Education Limited

Korir, J, Adoyo, p, Isaac, N, Aila, F.O, Mule, R.K, Ogut, A.S, dkk. 2015. Determinants of Tax Compliance among Small Taxpayers in Western Kenya.Greener Journal of Economics and Accountancy ISSN: 23542357 Vol. 4 (1), pp. 009-020, January 2015.

Lumbantoruan, S., 2007. Akuntansi Pajak, Jakarta: Grasindo.

Mardiasmo. 2012. Perpajakan. Yogyakarta: Penerbit Andi.

Mavengere, K. 2015. An Analysis of Factors Affecting Tax Compliance among SME's In Zimbabwe. A Case of Bulawayo Small Medium Enterprises (SMEs).International Journal of Management Sciences and Business Research, Aug-2015 ISSN (22268235) Vol-4, Issue 8

Moeinadin, M, Heirany,F dan Harandi, A. 2014. Identifying the Effective Factors 
Diki Ferdiana, Ayu Chairina Laksmi -- Pengaruh Proses Pelaporan Dan Penyetoran Pajak Serta Kepuasan Dan Kepatuhan Dalam Wajib Pajak Pribadi Kabupaten Sleman Terhadap Ketahanan Ekonomi Wilayah

for the Improvement of Tax Compliance. International Journal of Academic Research in Accounting, Finance and Management Sciences Vol. 4, No.1, January 2014, pp. 220-227 E-ISSN: 2225-8329, P-ISSN: 2308-0337 (C) 2014 HRMARS www.hrmars.com

Nasucha, C. 2009. Reformasi Administrasi Publik: Teori dan Aplikasi. Jakarta: PT Gramedia Widiasarana Indonesia.

Nkwe, N. 2013. Tax Payers' Attitude and Compliance Behavior among Small Medium Enterprises (SMEs) in Botswana. Business and Management Horizons. Macrothink Institute. ISSN 2326-0297 2013, Vol. 1, No. 1

Nurmantu, S., 2008. Pengantar Perpajakan, Jakarta: Kelompok Yayasan Obor

Panayiotis, N. 2014. Tax Compliance, Social Norms and Institutional Quality: An Evolutionary Theory of Public Good Provision. Taxation Papers. Working Paper N. 46-2014. ISSN 1725-7565 (PDF) ISSN 1725-7557 (Printed)

Surjoputro, D.S dan Widodo, J.E. 2009. Meningkatkan Kepatuhan Wajib Pajak Melalui Modernisasi Administrasi Perpajakan. Jakarta: Penerbit Kharisma.
Tarmini, LT., 1992. Ekonomi Pembangunan, Jakarta: PAU Studi Ekonomi-UI

Tjiptono, F. 2012. Service, Quality \& Statisfaction. Yogyakarta: Andi Offset.

Wijaya, T. 2009. Analisis Structural Equation Modeling Menggunakan AMOS. UAJY Yogyakarta.

Wolk, A.J. 2001. Signaling, Agency Theory, Accounting Policy Choice. Accounting and Business Research. Vol. 18. No 69:47-56

Zauhar, S. 2002. Reformasi Administrasi: Konsep, Dimensi dan Strategi. Jakarta: Penerbit Bumi Askara.

\section{Peraturan Perundangan}

Undang-Undang Nomor 25 Tahun 2009 Tentang Pelayanan Publik

Peraturan Menteri Keuangan No. 206.2/ PMK.01/2014 Tentang Organisasi dan Tata Kerja Instansi Vertikal Direktorat Jenderal Pajak.

Peraturan Menteri Pendayagunaan Aparatur Negara No. 16 Tahun 2014 Tentang Pedoman Survei Kepuasan Masyarakat Terhadap Penyelenggaraan Pelayanan Publik. 